\title{
How vigorously should we exercise our rheumatoid arthritis patients?
}

The deleterious effects of joint inflammation on joint mobility, muscle strength, and daily function have been well recognised. The traditionally prescribed local and systemic rest for the inflamed joints will increase these adverse effects. Physiotherapy, in particular, exercise therapy, is therefore one of the cornerstones of the management of rheumatoid arthritis. The primary goal of exercise therapy is to improve joint mobility, muscle strength, and aerobic and functional capacity. Gentle passive and active range of motion (ROM) exercises together with isometric muscle exercises are the most frequently prescribed treatments and are still recommended in the textbooks, in particular for the patients with active disease. Weight bearing and conditioning exercises have long been discouraged because of fear of damaging the joints. But are isometric and stretching exercises powerful enough to improve muscle strength, physical condition, and ultimately functional capacity? Functional capacity, in particular, is the major outcome variable of our therapeutic efforts in rheumatoid arthritis. Therapeutic interventions capable of improving functional capacity have, therefore, high priority.

\section{Exercise therapy: short term effects}

Isometric exercises can result in a moderate increase of quadriceps muscle strength, ${ }^{12}$ but improvement of joint mobility and aerobic condition is equally important as a goal of exercise therapy in inflammatory arthritis. There have been no randomised trials showing that the traditionally prescribed exercise therapy-consisting of stretching and isometric exercises-improves joint mobility, aerobic condition, or functional capacity. Views about exercise are changing, however, since several studies have shown that patients with rheumatoid arthritis can participate in aerobic and weight bearing exercise classes without an increase in disease activity or detrimental effects in the short term. ${ }^{2-12}$ Only six of these studies had a randomised design and the exercise programmes varied in type, intensity, and frequency ${ }^{24671011}$ (table). Four of these studies showed that aerobic condition improved in the dynamic exercise groups employing aerobic and weight bearing exercises, cycling, and aquatic exercises. ${ }^{246}{ }^{7} \mathrm{~A}$ statistically significant improvement in muscle strength was found in three studies with dynamic exercises. ${ }^{2710}$ Joint mobility was measured in three studies, ${ }^{267}$ of which only one showed a significant increase in joint mobility in the group receiving dynamic training and ROM exercises. ${ }^{2}$ In contrast to the negative expectations, disease activity in all six randomised studies seemed to decrease in the dynamic exercise groups. Physical capacity-whether measured by several unvalidated questionnaires or by the $\mathbf{5 0}$ foot walking time, the stair test, or grip strength-improved significantly within all dynamic exercise groups. The health assessment questionnaire (HAQ) was either not measured, or showed no significant improvement. The HAQ score does not, however, cover endurance, work capacity, and general health-dimensions of health status which are particularly amenable to conditioning exercises. It is also conceivable that significant changes in functional capacity as measured by the HAQ score only become apparent after a continued period of dynamic conditioning exercises. In elderly people an association has been shown between a long term routine of regular exercise and maintenance of function. ${ }^{1314}$

\section{Intensive dynamic exercise: long term effects}

Knowledge about the long term effects of dynamic, weight bearing exercises is very limited (table). The only randomised study compared five different exercise programmes and found no differences in disease activity, muscle strength, aerobic condition, functional capacity, or radiographic scores. ${ }^{15}$ The number of patients included in the different exercise groups was small, however, resulting in a study with insufficient power to detect a real difference. The two other studies investigating the long term effects of intensive dynamic training in rheumatoid arthritis were not randomised. ${ }^{16}{ }^{17}$ In these studies the intensively trained rheumatoid arthritis patients were more capable of performing the activities of daily living than the rheumatoid arthritis controls. ${ }^{16-18}$ The control rheumatoid arthritis patients spent twice as many days in hospital. Furthermore they significantly more frequently either took sick leave or had a sickness pension than the intensively trained rheumatoid arthritis patients. ${ }^{16}$ After a mean observation period of five years the trained rheumatoid arthritis patients appeared to have a smaller increase in the radiological score of the lower extremities than the control patients. ${ }^{16}$ The results of this study, however, could easily have been biased by the fact that only symptomatic joints had been radiographed. Although these studies seem to be in favour of the long term training of arthritis patients, well designed randomised trials are needed to establish the long term effects of intensive dynamic training on functional capacity, joint damage, and medical costs.

A short course of intensive training will probably not result in a lasting positive effect on physical capacity, since it has been shown that three to six months after finishing the exercise programme the gain in physical capacity had decreased. ${ }^{2}{ }^{2}$ It is generally known that continued exercise is needed to maintain physical fitness. Ekblom et al ${ }^{19}$ found that only the patients who continued to train four times or more per week had maintained the improved physical status acquired during the initial conditioning. Active exercise behaviour after finishing an exercise programme is associated with high physical activity and aerobic capacity at the start of the exercise programme. ${ }^{2021}$ Exercise therapy will be especially effective in patients who do not have enough self discipline to exercise on their own. It is not surprising that home exercise programmes have failed to establish significant improvements in physical impairments. ${ }^{2122}$ In improving and maintaining physical capacities, close supervision of exercises might be a crucial factor.

A side effect of continued weight bearing exercise will be the beneficial effect on bone density. ${ }^{23}{ }^{24}$ Accelerated generalised osteoporosis induced by active inflammation and immobility is a well known complication of rheumatoid arthritis. ${ }^{25-27}$ Muscle mass and physical condition as measured by the maximum oxygen uptake are important predictors of bone density. ${ }^{23} \mathrm{~A}$ rapid loss of bone mass and muscle strength will occur during flares of the arthritis. None of the earlier mentioned studies has addressed the question of whether dynamic exercises are feasible in active rheumatoid arthritis. Until now there has been a general consensus that dynamic exercises are probably inappropriate in patients with an acute flare of rheumatoid arthritis and that the first choice of exercise therapy is of gentle stretching and non-weight-bearing isometric exercises. At present we have a study in progress here comparing 
Summary of the results of the most important controlled exercise trials

\begin{tabular}{|c|c|c|c|c|c|c|c|c|c|c|}
\hline $\begin{array}{l}\text { First author } \\
\text { (reference) }\end{array}$ & $\begin{array}{l}\text { No of } \\
\text { patients }\end{array}$ & $\begin{array}{l}\text { Randomisation/ } \\
\text { blinding }\end{array}$ & Duration & Frequency & Type of exercise & $\begin{array}{l}\text { Aerobic } \\
\text { capacity }\end{array}$ & $\begin{array}{l}\text { Muscle } \\
\text { strength }\end{array}$ & $\begin{array}{l}\text { foint } \\
\text { mobility }\end{array}$ & $\begin{array}{l}\text { Function } \\
\text { (self-assessment) }\end{array}$ & $\begin{array}{l}\text { Disease } \\
\text { activity }\end{array}$ \\
\hline $\begin{array}{l}\text { Van den } \\
\text { Ende }^{2}\end{array}$ & 100 & Yes/no & 12 weeks & $3 \times$ per week & Cycling, dynamic training & ++ & ++ & ++ & $=\mathrm{HAQ}$ & $\begin{array}{l}++ \text { swollen } \\
\text { joints }\end{array}$ \\
\hline Harkcom ${ }^{4}$ & 20 & Yes/no & 12 weeks & $3 \times$ per week & Cycling & + & $=$ & & $\begin{array}{l}\text { =Functional } \\
\text { Status Index }\end{array}$ & $\begin{array}{l}\text { +swollen } \\
\text { joints }\end{array}$ \\
\hline Minor $^{6}$ & 40 & Yes/no & 12 weeks & $3 \times$ per week & Aquatics, walking & ++ & & + & $\begin{array}{l}++ \text { anxiety, } \\
\text { depression }\end{array}$ & $\begin{array}{l}\text { +morning } \\
\text { stiffness }\end{array}$ \\
\hline Ekdahl $^{7}$ & 67 & Yes/yes & 6 weeks & $\begin{array}{l}1-2 \times \text { per week }+ \\
\text { home exercise }\end{array}$ & Dynamic training & ++ & ++ & $=$ & $=$ & $=$ \\
\hline Hakkinen $^{10}$ & 39 & Yes/no & 6 months & $2-3 \times$ per week & Resistance exercise training & & ++ & & $+\mathrm{HAQ}$ & $=$ \\
\hline Lyngberg ${ }^{11}$ & 24 & Yes/yes & 12 weeks & $2 \times$ per week & $\begin{array}{l}\text { Cycling, heel lifts, step } \\
\text { climbing }\end{array}$ & $=$ & $=$ & & $=$ Fries index & $=$ \\
\hline Hansen $^{15}$ & 75 & Yes/yes & 2 years & $\begin{array}{l}1-2 \times \text { per week }+ \\
\text { home exercise }\end{array}$ & $\begin{array}{l}\text { Swimming, cycling, } \\
\text { running }\end{array}$ & $=$ & + & $=$ & $=\mathrm{HAQ}$ & $=$ \\
\hline Nordemar $^{1618}$ & 52 & No/no & $4-8$ years & $>5$ hours per week & $\begin{array}{l}\text { Swimming, skiing, cycling, } \\
\text { dancing, golfing }\end{array}$ & $=$ & ++ & & $\begin{array}{l}\text { ++sick leave, } \\
++ \text { ADL tasks }\end{array}$ & $=$ \\
\hline Stenstrom ${ }^{17}$ & 60 & No/yes & 4 years & $1 \times$ per week & Aquatics & & & & ++hospital care & $=$ \\
\hline
\end{tabular}

$=$, no changes within training group; + , significant improvement within training group; ++ , significant improvement between groups.

dynamic with isometric exercise therapy in rheumatoid arthritis patients admitted because of an acute flare of the arthritis. So far no great problems have arisen, but we have to await the final results.

Although the long term effects of dynamic weight bearing exercise are still unclear, the available data show that, if we aim at improving joint mobility, muscle strength, and aerobic conditioning, we should vigorously exercise our rheumatoid arthritis patients. There is no evidence that this approach will exacerbate the arthritis and there is no reason to fear progressive radiological damage. Vigorous exercise therapy may be the strategy of first choice unless proof of serious long term sequelae emerges. The benefits to general health, independence, and medical costs will in the end determine the usefulness of this strategy.

$\mathrm{J} M$ W HAZES C H M VAN DEN ENDE

Department of Rheumatology,

Leiden University Hospital,

PO Box 9600, 2300 RC Leiden,

The Netherlands

1 Machover S, Sapecky AJ. Effect of isometric exercise on the quadriceps muscle in patients with rheumatoid arthritis. Arch Phys Med Rehabil 1966; 47:737-41.

2 Van den Ende CHM, Hazes JMW, le Cessie S, Mulder WJ, Belfor DG, Breedveld FC, et al. Comparison of high and low intensity training in patients with well controlled rheumatoid arthritis. Results of a randomised clinical trial. Ann Rheum Dis 1996;55:798-805.

3 Ekblom B, Lövgren O, Alderin M, Fridström M, Sätterström G. Effect of short-term physical training on patients with rheumatoid arthritis I. Scand f Rheumatol 1975;4:80-6.

4 Harkcom TM, Lampman RM, Banwell RF, Castor CW. Therapeutic value of graded aerobic exercise in rheumatoid arthritis. Arthritis Rheum 1985;28:32-9.

5 Lyngberg KK, Danneskiold-Samsoe B, Halskov O. The effect of physical training on patients with rheumatoid arthritis, changes in disease activity,
muscle strength and aerobic capacity. Clin Exp Rheumatol 1988;6:253-60.

6 Minor MA, Hewett JE, Webel RR, Anderson SK, Kay DR. Efficacy of Minor MA, Hewett JE, Webel RR, Anderson SK, Kay DR. Efficacy of
physical conditioning exercise in patients with rheumatoid arthritis and physical conditioning exercise in patients with rh

7 Ekdahl C, Andersson SI, Moritz U, Svensson B. Dynamic versus static training in patients with rheumatoid arthritis. Scand $f$ Rheumatol $1990 ; 19 \cdot 17-26$.

8 Perlman SG, Connell KJ, Clark A, Robinson MS, Conlon P, Gecht M, Caldron P, Sinacore JM. Dance-based aerobic exercise for rheumatoid arthritis. Arthritis Care Res 1990;3:29-35.
9 Kirsteins AE, Dietz F, Hwang SM. Evaluating the safety and potential use of a weight-bearing exercise, Tai-Chi Chuan, for rheumatoid arthritis a weight-bearing exercise, Tai-Chi Chuan, for
patients. Am $\mathcal{f}$ Phys Med Rehabil 1991;70:136-41.

10 Hakkinen A, Hakkinen K, Hannonen P. Effects of strength training on neuromuscular function and disease activity in patients with recent-onset inflammatory arthritis. Scand $\mathcal{F}$ Rheumatol 1994;23:237-42.

11 Lyngberg KK, Harreby M, Bentzen H, Frost B, Danneskiold-Samsoe B. Elderly rheumatoid arthritis patients on steroid treatment tolerate physical training without an increase in disease activity. Arch Phys Med Rehabil 1994;75:1189-95.

12 Noreau L, Martineau H, Roy L, Belzile M. Effects of a modified dance-based exercise on cardiorespiratory fitness, psychological state and health status of persons with rheumatoid arthritis. Am $\mathcal{F}$ Phys Med Rehabil 1995;74:19-27.

13 Branch LG. Health practices and incident diasability among the elderly. $\mathrm{Am}$ f Public Health 1985;75:1436-9.

14 Mor V, Murphy J, Masterson-Allen S, Willey C, Razmpour A, Jackson ME, et al. Risk of functional decline among well elders. $\mathcal{F}$ Clin Epidemiol 1989; 42:895-904.

15 Hansen TM, Hansen G, Langgaard AM, Rasmussen JO. Longterm physical training in rheumatoid arthritis. A randomized trial with different training programs and blinded observers. Scand $\mathcal{f}$ Rheumatol 1993;22:107-12.

16 Nordemar R, Ekblom B, Zachrisson L, Lundqvist K. Physical training in rheumatoid arthritis, a controlled long-term study I. Scand 7 Rheumatol 1981;10:17-23.

17 Stenstrom CH, Lindell B, Swanberg E, Swanberg P, Harms-Ringdahl K, Nordemar R. Intensive dynamic training in water for rheumatoid arthritis functional class II - a long-term study of effects. Scand $\mathcal{F}$ Rheumatol 1991; 20:358-65.

18 Nordemar R. Physical training in rheumatoid arthritis: a controlled long-term study. II. Scand $\mathcal{F}$ Rheumatol 1981;10:25-30.

19 Ekblom B, Lovgren O, Alderin M, Fridstrom M, Satterstrom G. Effect of short-term physical training on patients with rheumatoid arthritis. A six-month follow-up study. Scand $\mathscr{f}$ Rheumatol 1975;4:87-91.

20 Minor ME, Brown JD, Exercise maintenance of persons with arthritis after participation in a class experience. Health Educ $Q$ 1993;20:83-95.

21 Daltrov LH, Robb-Nicholson C, Iversen MD, Wright EA, Liang MH. Effectiveness of minimally supervised home aerobic training in patients
with systemic rheumatic disease. $B r \mathcal{F}$ Reumatol 1995;34:1064-9.

22 Stenstrom CH, Arge B, Sundbom A. Dynamic training versus relaxation training as home exercise for patients with inflammatory rheumatic diseases. Scand F Rheumatol 1996;25:28-33.

23 Schoutens A, Laurent E, Poortmans JR. Effects of inactivity and exercise on bone. Sports Med 1989;7:71-81.

24 Gerber NJ. Can exercise prevent osteoporosis? Br f Rheumatol 1991;30:2-4.

25 Joffe I, Epstein S. Osteoporosis associated with rheumatoid arthritis: pathogenesis and management. Semin Arthritis Rheum 1991;20:256-72.

26 Laan RFJM, van Riel PLCM, van de Putte LBA. Bone mass in patients with rheumatoid arthritis. Ann Rheum Dis 1992;51:826-32.

27 Eggelmeijer F, Camps JAJ, Valkema R, Papapoulos SE, Pauwels EKJ, Dijkmans BAC, et al. Bone mineral density in ambulant non-steroid treated female patients with rheumatoid arthritis. Clin Exp Rheumatol 1993; 11:381-5. 